\title{
Влияние УФ-излучения на усилительные свойства легированного эрбием кварцевого волокна, насыщенного молекулярным водородом
}

\author{
А.П. Базакуца", К.М. Голант, О.В. Бутов \\ ИРЭ им. В.А. Котельникова РАН \\ *E-mail: abazakutsa@gmail.com
}

DOI:10.31868/RFL2018.164-165

Разработка волоконных лазеров с распределенной обратной связью (РОС) на основе высоколегированных редкоземельными примесями кварцевых оптических волокон является актуальной задачей $[1,2]$. Резонатором такого лазера является волоконная брэгговская решётка с фазовым-сдвигом [3]. Запись такой решетки, как правило, осуществляется с помощью излучения лазера УФдиапазона [3]. Для обеспечения необходимой для записи решетки фоточувствительности сердцевину волоконного световода легируют германием. Однако квантовая эффективность люминесценции эрбия при повышении его концентрации в сетке стекла сердцевины в присутствии германия может снижаться [4], при том, что именно высокая концентрация эрбия в сердцевине световода позволяет создавать волоконные РОС лазеры с коротким резонатором без солегирования ионами $\mathrm{Yb}$. Альтернативным решением вопроса повышения фоточувствительности может являться насыщение активного волокна молекулярным водородом [5]. В работе [6] было описано влияние $\mathrm{H}_{2}$ на люминесцентные свойства активных волокон. При этом, как показано в [7], воздействие облучения таких волокон УФ требует дополнительного изучения. В нашей работе было проведено исследование влияния ультрафиолетового облучения легированного $\mathrm{Er}$ волоконного световода, насыщенного $\mathrm{H}_{2}$, на его усилительные свойства.

В наших экспериментах исследовалось одномодовое активное оптоволокно из плавленого кварца, легированное эрбием, вытянутое из заготовки, изготовленной с применением технологии SPCVD [8]. Концентрация редкоземельных ионов $\mathrm{Er}^{3+}$ в сердцевине волокна, вычисленная из величины поглощения на характерной длине волны 1530 нм $180 \mathrm{~dB} / \mathrm{m}$ составила $3.74 * 10^{20}$ $\mathrm{cm}^{-3}$. Основным параметром, который исследовался в наших экспериментах, было усиление в активном волокне на длине волны 1550 нм. Измерение проводилось по классическому методу cut-back [3]. Схема эксперимента на рис. 1.

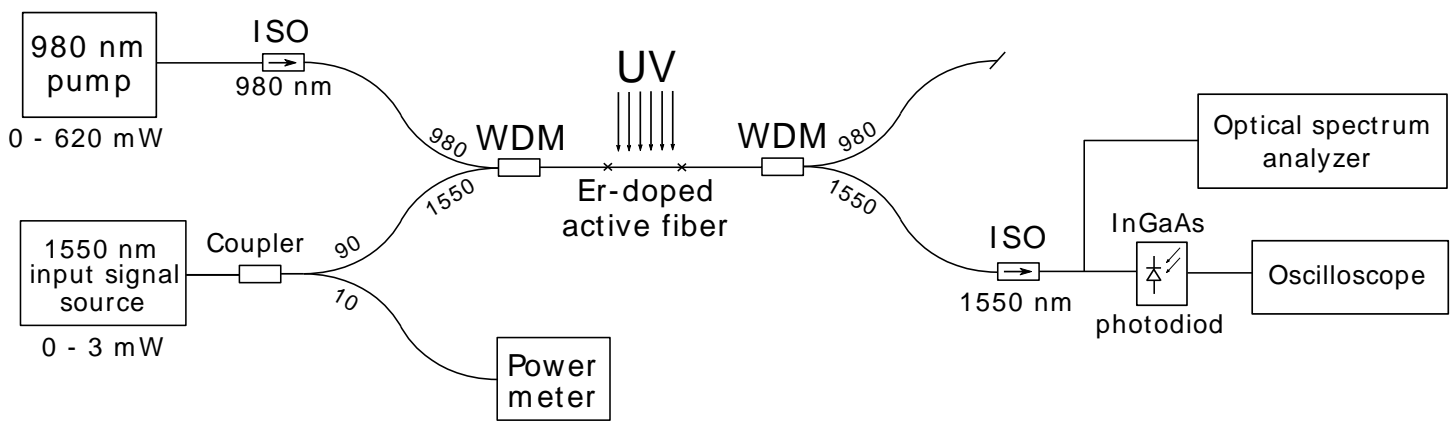

Рис. 1 Схема эксперимента.

На рис. 2 показано усиление малого сигнала $(1 \square \mathrm{W})$ в активном волокне до и после насыщения молекулярным водородом, а также спустя различные 
интервалы времени после УФ облучения эксимерным лазером на длине волны 193 нм. Доза, полученная каждым образцом, составила 0,75 кДж/ см². Как видно из графика, насыщение водородом, равно как и облучение УФ волокон без водорода приводит к небольшому $\sim 10 \%$ уменьшению усиления, в то время как облучение волокна, предварительно насыщенного молекулярным водородом приводит к уменьшению усиления более чем вдвое при максимальной мощности накачки. С течением времени усиление частично восстанавливается после облучения, что объясняется выходом несвязанного $\mathrm{H}_{2}$ из волокна.

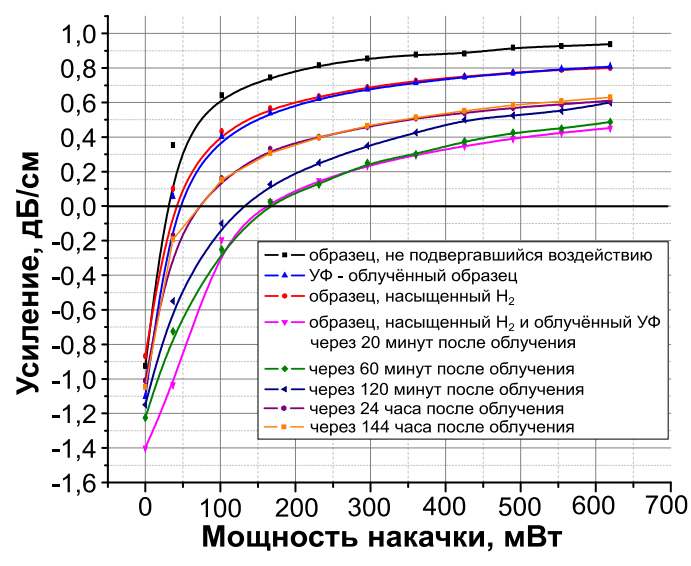

Рис. 2. Изменение усиления с течением времени после облучения УФ насыщенного $\mathrm{H}_{2}$ волокна.

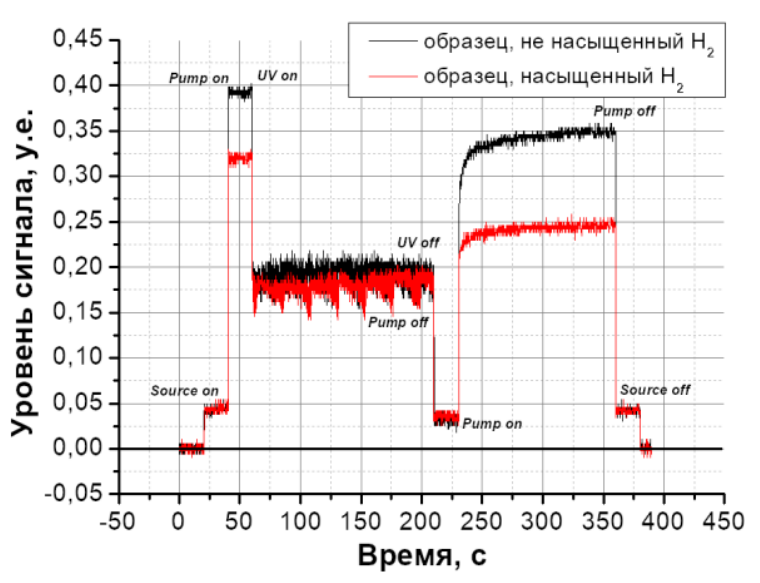

Рис. 3. Изменение усиления в процессе облучения УФ насыщенного $\mathrm{H}_{2}$ волокна.

Кроме того, было проведено измерение величины усиленного сигнала после образца активного волокна 'in situ' в процессе облучения УФ для насыщенных и не насыщенных молекулярным водородом образцов (рис. 3). Было показано, что в результате УФ облучения насыщенного водородом активного волокна в нём образуются дефекты двух типов. Дефекты первого типа, не связанные с присутствием водорода в сетке стекла, частично распадаются под воздействием излучения накачки на 980 нм, причём характерное время этого распада составляет $\sim 3$ с. Дефекты второго типа, ассоциированные с присутствием водорода за рассматриваемый промежуток времени не распадаются.

Работа поддержана Российским Фондом Фундаментальных Исследований (РФФИ) (проект А 17-07-01388)

\section{Литература}

[1] M. Sejka, et al, Electron. Lett., 31, no. 17, 1445-1446, (1995).

[2] S. A. Babin, et al, Laser Phys. 17, 1292-1295 (2007)

[3] Oleg V. Butov, et al, Journal of the Optical Society of America B, 34, No.3, A43-A48, (2017)

[4] A.V.Kholodkov, K.M.Golant, Semiconductor Device Research Symposium, 90 - 91, (2003)

[5] O. V. Butov, et al, Progress In Electromagnetics Research Symposium (PIERS), St.Petersburg, Russia, $22-25$, (2017)

[6] A.P. Bazakutsa, K.M. Golant, Journal of Non-Crystalline Solids, 411, 68 - 75, (2015)

[7] Wen Liua,b, John Canning et.al., International Conference on Optical Fibre Sensors (OFS24), Proc. of SPIE, 9634, 96344F-1 - 96344F-4, (2015)

[8] E.M. Dianov, et al, Journal of Lightwave Technology, 13, No. 7, 1471 - 1474, (1995) 